\title{
Cholinesterase Enzymes as Predictors for Severity Among Acutely Organophosphorus Intoxicated Patients
}

\author{
Alyaa A. A. Othman ${ }^{1}$, Hend M. H. Abo El-Atta ${ }^{1}$, Seham Aly Gad-ElHak ${ }^{1}$, Abdel-Aziz A.Ghanem ${ }^{1}$
}

\begin{abstract}
KEYWORDS

Organophosphorus,

Predictor,

Cholinesterase,

Severity,

Toxicity,

POP.

Organophosphorus pesticides are considered a major human health concern, primarily in developing countries. Acute toxicity of these compounds is known to have serious health consequences. The study aimed to assess the role of cholinesterase enzymes (acetylcholinesterase and butyrylcholinesterase) as predictors for severity following acute OP intoxication immediately after admission, using Peradeniya Organophosphorus Poisoning (POP) clinical severity scoring. It was conducted on fifty patients recruited from Mansoura University Emergency Hospital with history of acute exposure to organophosphorus compounds (OPCs). Detection of OP toxicity was done using thin layer chromatography (TLC) technique; assessment of severity of OP poisoning was done using Peradeniya Organophosphorus Poisoning (POP) scale; and estimating ACHE and BuCHE levels that was done using microlab auto-analyzer. No statistically significant associations were found between initial ACHE enzyme levels and POP severity scoring $(p=0.075)$, meanwhile, initial BuCHE levels were significantly associated with POP severity scoring $(p=0.045)$. Thus, measurement of BuCHE enzyme on admission is a sensitive biomarker for acute OP exposure and severity. Although ACHE enzyme is considered a specific biomarker for diagnosis of OP toxicity, it cannot be considered a sensitive biomarker for severity.
\end{abstract}

\section{Introduction}

Organophosphates (OPs) are class of chemicals widely used for prevention of harmful effects of many pests. Their worldwide use is increased to control diseases' vectors and increase food production. They are inhibitors of carboxylic ester hydrolases within the body, including cholinesterases. Their inhibition is considered the main mechanism of action and the clinical effects of other interactions are not well understood (Watson et al., 2015).

Mammalian cholinesterases represent a family of enzymes that hydrolyse choline esters

(1) Forensic Medicine and Clinical Toxicology
Department, Faculty of Medicine,
University.

and divided into two major classes: acetyl or red cell cholinesterase and plasma, pseudo or butyrylcholinesterase, regarding substrate preference, sensitivity to specific inhibitors, their location, active site and function (Chowdhary et al., 2014). Inhibition of acetylcholinesterase (ACHE) enzyme is generally thought to account for the majority of clinical features of organophosphorus (OP) poisoning. Both ACHE and butyrylcholinesterase (BuCHE) can be inactivated by OPs. Therefore, depression of their activities in the blood is a validated biomarker of OP exposure (Morris et al., 2014).

Strelitz et al. (2014) studied the relationship between $\mathrm{ACHE}$ and $\mathrm{BuCHE}$ as biomarkers for diagnosis of OP poisoning, and 
assessed whether these measures can be used interchangeably and found a weak negative association. It is unclear which biomarker is the most appropriate for assessing severity of OP intoxication. The study aimed to assess the role of cholinestrase enzymes (ACHE and BuCHE) as predictors for severity following acute OP intoxication immediately after admission, using Peradeniya Organophosphorus Poisoning (POP) clinical severity scoring.

\section{Patients and Methods}

A cohort study was carried out on 199 patients presented with acute anticholinesterase poisoning in Mansoura University Emergency Hospital over a period of three years (from September 2014 to September 2017), 116 cases were diagnosed to be OP intoxicated; by thin layer chromatography (TLC). Only 50 patients of both sexes were included in this study, they were presented by acute OP poisoning and their ages ranged from 18 to 55 years. Other patients who presented with anaemia, cancer, chronic liver disease and diabetes mellitus, history of current alcohol consumption or pregnant women were excluded from the study.

All patients participated in the current study were requested to sign an informed consent form to indicate their approval to participate in the study. The study protocol was approved by the Institutional Review Board of Faculty of Medicine, Mansoura University (code no. 123). Each patient was subjected to the following steps:

1. History taking: including age, sex, residence, routes of exposure, manner of toxicity and household interferences.
2. Clinical evaluation: including general and systemic examination. Then, clinical severity scoring of the patients was assessed according to POP scale, which included pupil size, respiratory rate (R.R.), pulse rate, fasciculations, level of consciousness and the presence or absence of convulsions. Accordingly, subjects were divided into mild (POP score 0-3), moderate (POP score 4-7) and severe poisoning (POP score 8-11) groups (Kumar et al., 2015).

\section{Laboratory investigations:}

a.Chemicals and kits: all chemicals were analytically reagent grade: acetone "BDH"; acetylthiocholine iodide "MERK"; benzene "BDH"; 5, 5'-dithiobis (2-nitrobenzoic acid) (DTNB)"MERK"; Malathion (98\%) "MERK"; n-Hexane "BDH"; palladium chloride "MERK"; S-butyrylthiocholine iodide (BTC) "MERK"; Sodium dihydrogen phosphate $\left(\mathrm{NaH}_{2} \mathrm{PO}_{4}\right)$ "MERK"; sodium hydrogen phosphate $\left(\mathrm{Na}_{2} \mathrm{HPO}_{4}\right)$ "BDH"; sodium phosphate $\left(\mathrm{NaHPO}_{4}\right)$ "MERK"; sodium sulphate "Al-Gomhouria Company".

\section{b.Sampling:}

1.One hundred $\mathrm{ml}$ from gastric contents were collected in glass bottle $(200 \mathrm{ml})$ for detection of organophosphorus compounds (OPCs) by TLC and exclusion of non-OP pesticides.

2.Ten ml blood sample was taken; and then divided into two parts: five $\mathrm{ml}$ was kept without preservatives for estimation of BuCHE enzyme levels and the other sample (five $\mathrm{ml}$ ) was heparinized for estimation of ACHE enzyme activities. They were taken immediately after admission just before administration of any medications. 
c. Extraction of gastric samples and detection of OPs by TLC were done to confirm diagnosis according to Yang et al. (2012).

d.Measurement of ACHE enzyme activities was done according to Ellman method (Worek et al., 2012), using Microlab 200 auto-analyzer: Vital Scientific, 0435, Netherland.

e.Measurement of BuCHE enzyme levels was determined according to modified Ellman's method (Jońca et al., 2015),using Microlab 200 auto-analyzer: Vital Scientific, 0435, Netherland.

\section{Statistical Analysis}

The results were analyzed using student t-test. The significance level was kept at the level of less than $0.05(\mathrm{p}<0.05)$.

\section{Results}

The ages of the studied patients ranged from 18 to 55 years with a mean age $34.42 \pm 14.2$ years, most of them, 29 patients (58\%) were males. Rural and urban residents were nearly the same $(52 \%$ and $48 \%$ respectively).

Detailed history about toxic exposure was taken from all patients as shown in table (1), the major route of exposure was oral route $(58 \%)$. Regarding the manner of toxicity, occupational exposure was the commonest among the studied patients (42\%), meanwhile $38 \%$ of patients gave a history of deliberate self-poisoning, $12 \%$ gave history of accidental poisoning and alleged deliberate homicidal manner was the least manner of toxicity; in only $4 \%$ of patients. As regards household interferences, $80 \%$ of the studied patients came immediately to hospital without any household interference.

Table (1): Routes of exposure, manner of toxicity and household interferences among patients with organophosphate toxicity $(\mathrm{n}=50)$.

\begin{tabular}{|l|l|c|}
\hline \multicolumn{2}{|c|}{ Parameter } & n. (\%) \\
\hline \multirow{4}{*}{ Routes of exposure } & Oral & $29(58 \%)$ \\
\cline { 2 - 3 } & Dermal & $5(10 \%)$ \\
\cline { 2 - 3 } & Inhalation & $16(32 \%)$ \\
\hline \multirow{5}{*}{ Manner of toxicity } & Accidental & $6(12 \%)$ \\
\cline { 2 - 3 } & Occupational & $21(42 \%)$ \\
\cline { 2 - 3 } & Deliberate self-poisoning & $19(38 \%)$ \\
\cline { 2 - 3 } & Alleged deliberate homicidal & $4(8 \%)$ \\
\hline \multirow{3}{*}{ Household interferences } & Yes & $10(20 \%)$ \\
\cline { 2 - 3 } & No & $40(80 \%)$ \\
\hline
\end{tabular}

n.: number. 
Table (2) showed the findings of clinical examinations. Consciousness level was disturbed in $56 \%$ of patients. Majority of patients(50\%) presented with pinpoint pupils. Regarding the heart rates, $52 \%$ presented by severe bradycardia. Most of patients (76\%) presented with R.R. $<20$ breaths /min. Only $20 \%$ and $4 \%$ of patients presented by cyanosis and seizures respectively. Generalized and continuous muscle fasciculations were observed in $56 \%$ of patients, $66 \%$ were suffering from nausea and/or vomiting; $40 \%$ presented with urinary and/ or fecal incontinence; only $26 \%$ presented with excessive sweeting and 22\% were presented by excessive salivation.

Table (2): Frequencies of clinical manifestations of organophosphorus poisoning among the studied patients $(\mathrm{n}=50)$.

\begin{tabular}{|c|c|c|}
\hline & Manifestations & n. $(\%)$ \\
\hline \multicolumn{2}{|l|}{ Disturbed consciousness level } & $28(56 \%)$ \\
\hline \multirow{3}{*}{ Pupil size (mm) } & $\geq 2$ & $16(32 \%)$ \\
\hline & $<2$ & $9(18 \%)$ \\
\hline & Pinpoint & $25(50 \%)$ \\
\hline \multirow{3}{*}{ Pulse (beats/min) } & $<40$ & $26(52 \%)$ \\
\hline & $41-60$ & $15(30 \%)$ \\
\hline & $>60$ & $9(18 \%)$ \\
\hline \multirow{2}{*}{ Respiratory rate (breaths/min) } & $<20$ & $38(76 \%)$ \\
\hline & $>20$ & $12(24 \%)$ \\
\hline \multirow{2}{*}{ Cyanosis } & Yes & $10(20 \%)$ \\
\hline & No & $40(80 \%)$ \\
\hline \multirow{2}{*}{ Seizures } & Yes & $2(4 \%)$ \\
\hline & No & $48(96 \%)$ \\
\hline \multirow{3}{*}{ Fasciculations } & Absent & $9(18 \%)$ \\
\hline & Either generalized or continuous & $13(26 \%)$ \\
\hline & Generalized and continuous & $28(56 \%)$ \\
\hline \multicolumn{2}{|l|}{ Excessive salivation } & $11(22 \%)$ \\
\hline \multicolumn{2}{|l|}{ Nausea/vomiting } & $33(66 \%)$ \\
\hline \multicolumn{2}{|l|}{ Excessive sweeting } & $13(26 \%)$ \\
\hline \multicolumn{2}{|l|}{ Urinary/fecal incontinence } & $20(40 \%)$ \\
\hline
\end{tabular}

n.: number. 
Detection of OPs was done for all patients using TLC. There were specific spots for OPs in positive samples. Interestingly, different spots with different rates of flow were visualized in some samples; which suggests mixtures of the OP commercial preparations.

According to POP scale, $30 \%$ of patients were mild grade, $42 \%$ of patients were moderate, while, severe cases were found in $28 \%$ of patients. Table (3) demonstrates the association between POP scoring and cholinesterase enzymes levels.
As regard the initial levels of ACHE enzyme, no statistically significant difference was found between the three groups $(p=0.075)$. No statistically significant differences were found between (mild and moderate), (moderate and severe) and between (mild and severe) groups $(p=0.26 ; 0.39 ; 0.08$ respectively). Regarding the initial levels of BuCHE enzyme, there was a statistically significant difference between the three groups $(p=0.045)$. As well, statistically significant differences were found between (mild and moderate), (moderate and severe) and between (mild and severe) groups $(\mathrm{p}=0.0001$, each $)$.

Table (3): Association between Peradeniya Organophosphorus Poisoning scale and cholinesterase levels among patients.

\begin{tabular}{|c|c|c|c|c|}
\hline & Mild $(n=15)$ & Moderate $(n=21)$ & Severe $(n=14)$ & p-value \\
\hline \multirow{4}{*}{$\begin{array}{c}\text { ACHE }(\mu \text { moles } / \min \\
/ \mathrm{ml} \text { red cells }) \\
\text { mean } \pm \text { S.D }\end{array}$} & \multirow{4}{*}{$6.3 \pm 1.95$} & \multirow{4}{*}{$5.56 \pm 1.91$} & \multirow{4}{*}{$4.98 \pm 2.013$} & 0.075 \\
\hline & & & & $p_{1}=0.26$ \\
\hline & & & & $\mathrm{p}_{2}=0.39$ \\
\hline & & & & $\mathrm{p}_{3}=0.08$ \\
\hline \multirow{4}{*}{$\begin{array}{c}\text { BuCHE (IU) } \\
\text { mean } \pm \text { S.D }\end{array}$} & \multirow{4}{*}{$2181.94 \pm 191.26$} & \multirow{4}{*}{$1822.71 \pm 186.89$} & \multirow{4}{*}{$886.62 \pm 96.174$} & $0.045^{*}$ \\
\hline & & & & $\mathrm{p}_{1}=0.0001 *$ \\
\hline & & & & $\mathrm{p}_{2}=0.0001 *$ \\
\hline & & & & $\mathrm{p}_{3}=0.0001 *$ \\
\hline
\end{tabular}

ACHE: acetylcholinesterase. BuCHE: butyrylcholinesterase. S.D: standard deviation. $\mathbf{p}_{1}$ : difference between mild and moderate groups. $\mathbf{p}_{2}$ : difference between moderate and severe groups. $\mathbf{p}_{3}$ : difference between mild and severe groups.

\section{Discussion}

Organophosphorus compounds are commonly used in several countries; they act mainly by phosphorylation and subsequently inhibition of acetylcholinesterase which is responsible for classic clinical picture of acute OP poisoning (Watson et al., 2015). The present study aimed to assess the role of cholinesterase enzymes (ACHE and BuCHE) as predictors for severity following acute OP intoxication.

The association between POP scoring and the initial levels of ACHE didn't show any significant differences among the three groups, suggesting that initial ACHE levels are not specific indicators of the clinical severity. This is inconsistent with the previous study of 
Eddleston et al.(2008); they reported that ACHE enzyme activity varies significantly in mild, moderate and severe degrees of poisoning.

The present results are supported by Osman (2011) who stated that, the basic ACHE levels are generally low in chronically exposed individuals who live adjacent to regularly sprayed cotton fields. Roberts and Brett (2014) reported that symptoms are not always present in ACHE-depressed individuals; and there are differences between all OPCs regarding ACHE inhibition.

The weak contribution of initially measured ACHE levels in assessment of clinical severity of OP poisoning can be explained by the actual use of mixed formulation of pesticides (Eddleston et al., 2012).In the present study, TLC detection revealed multiple spots with different shapes and rates of flow, these findings are in accordance with previous studies conducted in Egypt by Farahat et al. (2010) and Farahat et al. (2011).

Additionally, it is difficult to know how closely ACHE inhibition in erythrocytes reflects that in the nervous system since access to blood is easier than brain. Thus, the inhibition of ACHE in erythrocytes may be overestimated relative to that in brain (Jokanović, 2012).

Furthermore, there are baseline variations of ACHE activity among individuals; it may be suppressed in healthy people (Watson et al., 2015).Therefore, the degree of inhibition of ACHE activity is ideally determined by comparing baseline activity measurements with others taken after the individual has been exposed (Strelitz et al., 2014). These comparisons were not feasible in the present study because the patients were firstly presented by acute toxicity, with no pre-exposure records for them.
As regards BuCHE enzyme, statistically significant associations have been demonstrated between the initial BuCHE enzyme levels and POP scale, which confirm its role as a sensitive biomarker for assessment of severity. Several studies have shown similar findings (Makwava et al., 2012; Hundekari et al., 2013; Khan et al., 2016). Suggesting that, the higher the score on POP scale, the higher was the degree of derangement in BuCHE levels.

However, these results were inconsistent with Jokanović (2012); Yun et al. (2012) and Hassan and Madboly (2013), they found that, primary inhibition of BuCHE enzyme didn't provide accurate information related to clinical severity. Yun et al. (2012) found that serial BuCHE measurements can better guide physicians in management of OP poisoned patients. This discrepancy can be explained by non specificity of BuCHE for OP exposure. Records demonstrated that this enzyme unlike ACHE may be suppressed in many other pathological conditions other than OP poisoning (Darwish et al., 2016).

In conclusion, according to results of the current study, measurement of BuCHE enzyme level on admission; strongly correlate with patient's clinical severity rather than ACHE enzyme. Serial measurements are recommended to better predict prognosis among intoxicated patients.

\section{References}

Chowdhary, S.; Bhattacharyya, R. and Banerjee, D. (2014): "Acute organ phosphorus poisoning". Clinica Chimica Acta, 431:66-76.

Darwish, R.T.; Megahed, H.M.; Ayad, M.W. and Barakat, A.A.A. (2016): "Study of acyl-peptide hydrolase as a probable marker of severity in cases of acute 
poisoning by cholinesterase enzyme inhibitor insecticides". Tanta Medical Journal, 44(1):4-11.

Eddleston, M.; Eyer, P.; Worek, F.; RezviSheriff, M. H. and Buckley, N.A. (2008): "Predicting outcome using butyrylcholinesterase activity in organophosphorus pesticide selfpoisoning". QJM: An International Journal of Medicine, 101(6):467-474.

Eddleston, M.; Street, J.M.; Self, I.; et al. (2012): "A role for solvents in the toxicity of agricultural organophosphorus pesticides". Toxicology, 294(2-3): 94-103.

Farahat, F.M.; Fenske, R.A.; Olson, J.R.; et al. (2010): "Chlorpyrifos exposures in Egyptian cotton field workers". Neurotoxicology, 31(3):297-304.

Farahat, F.M.; Ellison, C.A.; Bonner, M.R.; et al. (2011): "Biomarkers of chlorpyrifos exposure and effect in Egyptian cotton field workers". Environmental Health Perspectives, 119(6):801-806.

Hassan, N.A. and Madboly, A.G. (2013): "Correlation between serum creatine phosphokinase and severity of acute organophosphorus poisoning: A prospective clinical study (20122013)". IOSR Journal of Environmental Science, Toxicology and Food Technology, 4:18-29.

Hundekari, I.A.; Suryakar, A.N. and Rathi, D.B. (2013): "Acute organophosphorus pesticide poisoning in North Karnataka, India: oxidative damage, haemoglobin level and total leukocyte". African Health Sciences, 13(1):129-136.

Jokanović, M.(2012): Neurotoxic disorders and medical management of patients poisoned with organophosphorus and carbamate. In: The Impact of Pesticides. Jokanović, M.(Ed.), Academy Publish. org, USA, P.P. 39- 62.

Jońca, J.; Żuk, M.; Wasąg, B.; et al.(2015): "New insights into butyrylcholinesterase activity assay: serum dilution factor as a crucial parameter". PloSOne, 10(10): e 0139480 .

Khan, S.; Kumar, S.; Agrawal, S. and Bawankule, S. (2016): "Correlation of serum cholinesterase and serum creatine phosphokinase enzymes with the severity and outcome of acute organophosphorus poisoning: study in rural central India". Word Journal of Pharmacy and Pharmaceutical Sciences, 5 (4): 1365 1373.

Kumar, G.C.; Bhuvana, K.; Venkatarathnamma, P.N. and Sarala, N. (2015): "Serum creatine phosphokinase as predictor of intermediate syndrome in organo phosphorus poisoning". Indian Journal of Critical Care Medicine, 19 (7) : 384-387.

Makwava, P.V.; Odedara, R.V. and Shah, H.D. (2012): "Acute organophosphorus poisoning and clinical admission score association among patients admitted in emergency ward of a tertiary teaching hospital of medical college". Journal of Pharmaceutical and Biomedical Sciences, 17(8):1-5.

Morris, C.M.; Savy, C.; Judge, S.J. and Blain, P.G. (2014): Acute toxicity of organophosphorus compounds. In: Basic and Clinical Toxicology of Organo phosphorus Compounds. Balali-Mood, M. and Abdollahi, M. (Eds), SpringerVerlag, London, P.P. 45-78.

Osman, K.A. (2011): Pesticides and human health. In: Pesticides in The Modern World - Effects of Pesticides Exposure. 
Stoytcheva, M. (Ed.), InTech, Croatia, P.P. 205-230.

Roberts, D.M. and Brett, J. (2014): Clinical management of acute OP pesticide poisoning. In: Basic and Clinical Toxicology of Organophosphorus Compounds. Balali-Mood, M. and Abdollahi, M. (Eds.), Springer-Verlag, London, P.P. 141-175.

Strelitz, J.; Engel, L.S. and Keifer, M.C. (2014): "Blood acetylcholinesterase and butyrylcholinesterase as biomarkers of cholinesterase depression among pesticide handlers". Occupational and Environmental Medicine, 71(12):842-847.

Watson, A.; Opresko, D.; Young, R.A.;et al. (2015): Organophosphate nerve agents. In: Handbook of Toxicology of Chemical Warfare Agents, $2^{\text {nd }}$ ed. Gupta, R.C. (Ed), Elsevier Inc, USA, P.P. 87-110.
Worek, F.; Eyer, P. and Thiermann, H. (2012): "Determination of acetylcholinesterase activity by the ellman assay: a versatile tool for in vitro research on medical countermeasures against organophosphate poisoning". Drug Testing and Analysis, 4(34):282-291.

Yang, Z.; Liu, Y.; Liu, D. and Zhou, Z. (2012): "Determination of organophosphorus pesticides in soil by dispersive liquid-liquid microextraction and gas chromatography". Journal of Chromatographic Science, 50(1):15-20.

Yun, H.W.; Lee, D.H.; Lee, J.H.; Cheon, Y.J. and Choi, Y.H. (2012): "Serial serum cholinesterase activities as a prognostic factor in organophosphate poisoned patients". Hong Kong Journal of Emergency Medicine, 19(2):92-97. 


\title{
إنزيمات الكولين استريز كمتنبئات للخطورة بين المرضى المصابين بالتسمم الفسفوري العضوي الحاد
}

\author{
علياء أباا الحسن أحمل عثمان، هند محمود أبوالعطا، سهام علي جاد الحق، عبد العزيز أبو الفتوح غانم \\ قسم الطب الثرعي والسموم الإكلينيكية_ كلية الطب- جامعة المنصورة
}

تعتبر مبيدات الآفات الفوسفورية العضوية من الشو اغل الصحية الرئيسية خاصة في البلدان النامية.ومن التهن

المعروف أن السمية الحادة لهذه المركبات لها عو اقب صحية خطيرة. تهدف هذه الدر اسـة إلى قياس مستويات

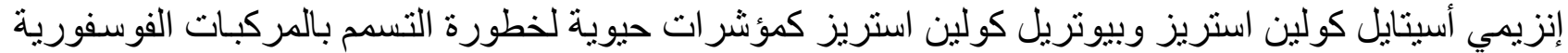
العضوية. وتم إجر اء هذه الدر اسة علي خمسين مريضًا قد تعرضو التئ اللتسمم الحاد بالمركبات الفسفورية العضوية

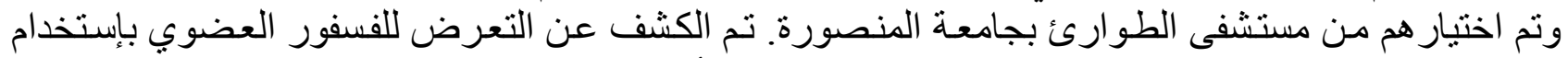

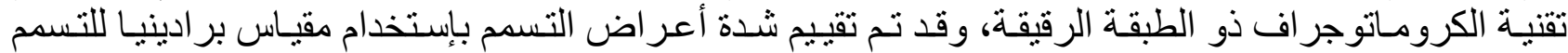

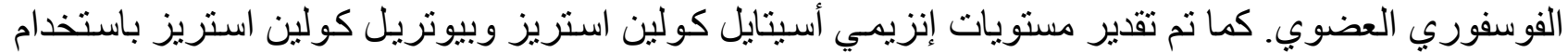

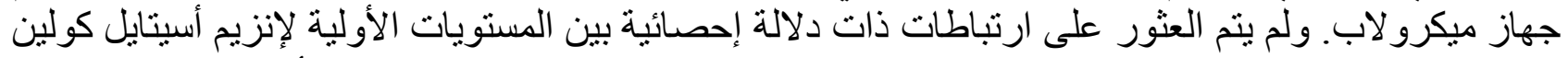
استريز ومقياس بر ادينيا، بينما كانت هنالك ارتباطات ذات دلالة إحصائية بين المستويات الأوليـة لإنزيم بيوتريل الإنزيل

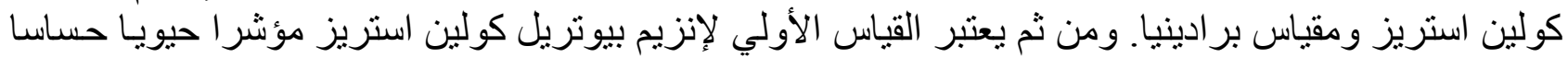

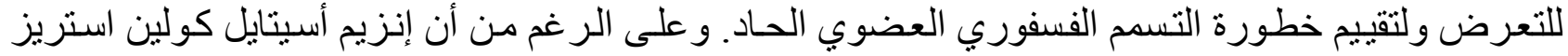

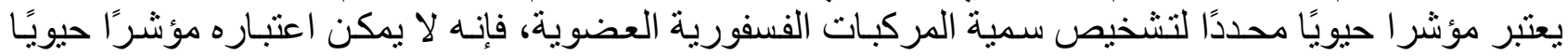

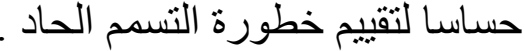

